\title{
Dualistic Audience Model in Public Diplomacy
}

\author{
Kalin Kalinov \\ Faculty of Journalism and Mass Communication SU "St. K1. Ohridski” \\ Дуалистичен модел на аудиторията в публичната дипломация \\ Калин Калинов \\ Факултет по журналистика и масова комуникация, СУ “Кл. Охридски”
}

\section{Author Note}

Kalin Kalinov (D) https://orcid.org/0000-0002-4367-7498

The article is part of the project "Dimensions and Transformations of Digital Public Diplomacy: Defining the Field, Communication Channels, Stakeholders and Measuring Effectiveness", funded by the National program "Young scholars and Postdoctoral Students" 2021.

The author has no conflict of interest to disclose.

Correspondence related to this article should be addressed to Kalin Kalinov, Faculty of Journalism and Mass Communication, Sofia University “St. K1. Ohridski” Sofia, Bulgaria.

Email: kkalinov@uni-sofia.bg

\section{Бележки за автора}

Калин Калинов (D) https://orcid.org/0000-0002-4367-7498

Авторът няма конфликт на интереси.

Статията е част от проект: „Измерения и трансформации на дигиталната публична дипломация: определяне на полето, комуникационни канали, заинтересовани страни и измерване на ефективността”, финансиран по Национална програма „Млади учени и докторанти" 2021. Кореспонденцията, с автора следва да бъде адресирана до Калин Калинов, Факултет по журналистика и масова комуникация, СУ „Св. Кл. Охридски” София, България. E-mail: kkalinov@uni-sofia.bg 


\begin{abstract}
This paper examines the theoretical frame regarding the audience with special focus on foreign diasporas as part of the potential stakeholders for initiatives in contemporary public diplomacy. Within the light of recent developments in digital communication and the widespread use of social media, we investigate the evolution of the concept for exclusively foreign audience in public diplomacy initiatives. The hypothesis of the author is that within the highly digitalized and globalized contemporary environment, it is impossible to completely separate domestic and foreign audiences. Thus, the dualistic Yin and Yang Model of the audience in public diplomacy is introduced. The concept can be useful for future theoretical and empirical research in the field, as well as a starting point for further academic debates and analysis.
\end{abstract}

Keywords: public diplomacy, yin and yang model, audience, audience in public diplomacy, audience model in public diplomacy

\title{
Резюме
}

Тази статия разглежда теоретичната рамка на аудиторията със специален акцент върху чуждестранните диаспори като част от потенциалните заинтересовани страни за инициативи в съвременната публична дипломация. В светлината на последните развития в цифровата комуникация и широкото използване на социалните медии, се изследва еволюцията на концепцията за изключително чужда аудитория в инициативите на публичната дипломация. Хипотезата на автора е, че в рамките на силно дигитализираната и глобализирана съвременна среда е невъзможно напълно да се разделят местната и чужда публика. Така се въвежда дуалистичният модел Ин и Ян на публиката в публичната дипломация. Концепцията може да бъде полезна за бъдещи теоретични и емпирични изследвания в областта, както и да послужи за отправна точка за по-нататьшни академични дебати и анализи.

Ключови думи: публична дипломация, ин и ян модел, публика, публика в публичната дипломация, модел на публиката в публичната дипломация

\author{
ARTICLE INFO: \\ Original Article \\ Received: 05, 09. 2021 \\ Revised: 16, 09. 2021 \\ Accepted: 15, 10.2021
}




\section{Dualistic Audience Model in Public Diplomacy}

There is little doubt that public diplomacy should be considered as a meeting point of communication and international relations. In this context, the general rules applicable to most information exchanges are in full force. As a result a key role in the communication act is reserved for the audience. In contemporary corporate communication practice, the audience is carefully profiled on the basis of demographics, socio-psychological characteristics and the development of buyer personas. However, when we turn our attention to political communication and particularly the one related to international relations, there are some key aspects that can be outlined.

Firstly, the idea of public diplomacy is to reach out to the mass audience. It is intended to gather wider support for political decisions relating to international relations. Kalinov defines the term in the following way:

"Every form of communication, which is aimed at a wide audience and related to the achievement of a political aim with international character" (Калинов, 2021, p. 88).

Thus, we can track the core idea of mass communication to the very heart of contemporary public diplomacy. In addition, the phenomenon has been impacted by recent developments in digital communication and particularly the mass adoption of social media as evidenced by a number of studies (Bjola, 2016; Manor, 2017). This has altered the profile of the key strategic audiences for initiatives in the field of public diplomacy. In turn, the means to reach them have also evolved. The article introduces the dualistic Yin and Yang Model of the audience in contemporary public diplomacy as a form of response to these newly arising challenges in the field.

\section{Methodology}

The article employs a wide theoretical review to properly frame the role of the audience in public diplomacy. It investigates different viewpoints with special emphasis on the classical paradigm based on the original Smith-Mundt Act (a.k.a. the U.S. Information and Educational Exchange Act of 1948), the alterations to the field dictated by the digitalization of communication and the mass adoption of social media, and last but not least - the concept of domestic and foreign audiences. In addition, partial historical approach is employed. It is particularly useful in tracing the American and British tradition in the investigated field. 


\section{Theoretical Review: The Concept of Audience in Public Diplomacy}

The audience is perhaps one of the most controversial topics in the contemporary academic debate related to public diplomacy initiatives. There is a severe collision of the classical paradigm in the field, which states that such communication initiatives should only be aimed at foreign audiences (Berridge \& James, 2003) and the more recent advancements, which adopt a flexible approach when it comes to audience definition (Melissen, 2011). Before delving into the depths of this controversy, we should differentiate the terms publics and stakeholders.

According to the classical business definition a stakeholder is a group or an individual who can influence and be influenced by the achievement of the organizational goals (Freeman, 2010, p. 25). The publics on the other hand are those who hinder or support the organization's achievement of said goals (Kim et al., 2008, p. 752). Grunig differentiates the terms by stating that stakeholders are chosen by the organization and the publics appear on their own and choose the structure (Grunig \& Repper, 1992, p. 128). Fitzpatrick adopts a different approach. She considers the terms to be interchangeable and suggests that "strategic publics" would give a clearer semantic approach (Fitzpatrick, 2012, p. 424).

Regardless of the academic debates, most practitioners agree that each organization should carefully profile the interested parties before conducting an initiative in the field of public diplomacy (Seip, 2016; Zaharna, 2011). The traditional interpretation in the field clearly states that such communication endeavors should be solely aimed at the citizens of other countries as standard diplomacy is conducted towards leaders of other states (Pratkanis, 2009, p. 112).

It can be assumed that the historical context of the term also plays a large part in this conceptualization. As many countries adopt the concept at a later stage (Fominykh, 2016; Ogawa, 2009; Zöllner, 2009), most of the early developments in public diplomacy relate to the British and American traditions (Cull, 2009). Some authors point towards the fact that avoiding interaction with domestic audiences limits the possibilities to compare the phenomenon to the negatively connotated term "propaganda" (Chitty, 2009).

In the American tradition the legal basis for government initiatives in the field is the SmithMundt Act a.k.a. The U.S. Information and Educational Exchange Act of 1948. In its core the document outlines the rules and procedures for addressing different audiences with public diplomacy actions. Furthermore, it regulates the broadcasting of state produced programs abroad 
and forbids their dissemination within the US. The main idea behind the Smith-Mundt Act was to limit the possibility for the US State Department to influence and indoctrinate people living in the country. This serves as the basis for framing the term "public diplomacy" in American context.

In the last decade the debate in the field has slightly shifted. The soft position presented by some scholars is that public diplomacy is aimed at foreign audiences but it becomes increasingly difficult to separate it from public affairs due to the interconnected realities of global interactions (Melissen, 2005, p. 13). Globalization inadvertently leads to more intensified international communication. As a result, practitioners in the field of public diplomacy are no longer in a position to present contrasting narratives to domestic and foreign audiences.

Some authors are even more expansive in their revisionist approach to the field. According to Gregory, for example, the distinct separation of domestic and foreign audiences was at its peak during the high point of the state system but has been in decline from the Middle Ages onwards (Gregory, 2015, p. 4). A large number of researchers point to the fact that even if domestic audiences are not the intended recipient of public diplomacy messages, they are residually impacted by them due to the inability to control the information flow (Heller \& Persson, 2009, p. 227; Huijgh, 2012, p. 359; Sukma, 2011). Turning attention to the practice, Rana states that most practitioners include communication with internal audiences within the public diplomacy framework (Rana, 2011, p. 78).

Returning to the American tradition, we already outlined the effect, which the Smith-Mundt Act had on its shaping. However, the contemporary practices in the field differ significantly from its original concept. Vlahos considers the possibility that the "War on Terror" has an important goal, which is to communicate to Americans themselves the realities of the new world (Vlahos, 2009, p. 26). Barstow goes even further in claiming that during the Iraq invasion many of the guests on morning talk shows were serving as virtual retainers for the Pentagon (Barstow, 2008). As a result, the American public diplomacy starts to look more as an internal communication campaign, which limits its possibility for international outreach (Armstrong, 2009, p. 64). This trend is further developed by the Smith-Mundt Modernization Act of 2012, which altered the legal framework in the US in order to authorize the domestic dissemination of materials within 
the country intended primarily for foreign audiences. Thus, even the legal grounding for the phenomenon has changed significantly.

Stepping outside of the American public diplomacy, we can note that the success of some initiatives in the field is largely connected to the active role of domestic audiences. For example, Norway's successful approach relies heavily on the national identity and the understanding of its citizens for their role in international politics. Pisarska defends the idea that the Norwegian case is clear indication that internal audiences should not be just informed about the government's decisions on foreign policy but should be brought in as equal partners in its formation (Pisarska, 2015 , p. 212). Others go even further by stating that contemporary democratic states would be unable to achieve their strategic goals without the involvement of domestic publics (Andrlić et al., 2012).

It is curious to follow the way larger international organizations conduct public diplomacy. When we consider structures like the EU and NATO, it is safe to assume that large part of their communication strategies aimed at the achievement of political goals are directed precisely at internal audiences. Of course, in their case this is quite understandable as the term practically includes all citizens of the member states. In addition, some initiatives can be considered as focused on domestic audiences. A prime example in this regard are The Commonwealth Games, which are mostly aimed at member states of the Commonwealth of Nations and are hardly promoted to states outside of the organization (Kobierecki, 2017).

Last but not least, we can outline two more interconnected problematic areas in defining public diplomacy as exclusively oriented towards foreign audiences. Where within the domestic-foreign spectrum can we place citizens of other countries who are residents within our own state? If we adopt a cultural perspective, these people clearly have a different national identity and upbringing. Geographically speaking, however, they are positioned within the territory of the country and thus are excluded as communication targets by the classical paradigm in the field, which is based on the original Smith-Mundt Act. Some authors claim that this is a new challenge in the field, which will have to be carefully addressed in the near future (Yun \& Toth, 2009, p. 493).

Just as complicated is the question with national diasporas in foreign states. They have the specific national and cultural identity but from a geographic perspective fall outside of the state 
borders. Some authors define them as key stakeholders or strategic publics due to their ability to be natural ambassadors between the state and the foreign audiences (Fitzpatrick, 2007; Signitzer \& Wamser, 2006). Bravo outlines them as complex publics that are quite heterogeneous in their composition. She further explains that foreign diasporas are significantly impacted by contextual factors such as the way they left their homeland and accepted the new environment, the characteristics of the immigrant community, time, space and others (Bravo, 2015).

In light of the stances presented above, it is clear that internal audiences can no longer be ignored as a factor in the international dialogue. The way a state behaves in its foreign policy has to be explained and justified in front of these publics. Thus, the gathered additional support can serve as an instrument, which enhances the achievement of the state's strategic goals. However, a possible conflict with these key audiences can significantly hinder the chances to achieve the pre-set objectives.

\section{The Yin and Yang Model}

In attempt to model the audience in public diplomacy, we are looking at the mass public, which is being targeted. Specialized structures like NGOs, non-formal working groups, etc. are not included in the presented dualistic model of the audience in the sector. The reason is that in order to establish the primary publics for widespread diplomacy messages, we need to escape the specialized cases and address the wider communication field. Thus, in the present model we are working exclusively with the mass audience, which is being targeted by public diplomats in their attempts to gather support for a particular idea or action in foreign policy.

The model is important for the sector as within the definition adopted earlier, public diplomacy initiatives are considered to be exclusively aimed at a wide audience. Better understanding of the segmentation within the general public can be helpful for both practitioners and academics in the field. The rationale behind such actions lies in the ability to generate active social support for a cause, an action or an idea on the international political scene.

Going back to the classical understanding of public diplomacy, we can note that it is mainly if not exclusively, aimed at foreign audiences. The concept has been discussed at length in earlier sections of the paper. However, the social and technological changes have led to significant alterations in the way public diplomacy is conducted. Even the legal framework behind such initiatives in the US - the Smith-Mundt Act has been revised. This is largely a result of important 
changes in the social practice itself. Contemporary public diplomacy is based on two-sided communication, dialogue, building long-term relationships and all of this is clearly reflected in the different applications in the field.

In the theoretical review we established that there are many representatives of the so-called new public diplomacy (Melissen, 2011). While it still differentiates between domestic and foreign audiences, the paradigm acknowledges that it becomes increasingly difficult to separate public affairs from international communication. This convergence in the sector should be clearly reflected in modelling the audience of public diplomacy initiatives.

Additionally, we looked at national diasporas in other countries and foreign diasporas as a domestic factor. Both of these groups have very specific and heterogeneous characteristics. National diasporas abroad are in a unique position to serve as a bridge between the actions and positions of a government and key foreign publics. In order for that to happen, the communication with these communities has to be very precise. The reason is that an ineffective approach can antagonize them but overly persuasive one can indoctrinate them and compromise their role as a mediator. Thus, working with such groups requires patience and good sense of balance of the moods and ideological formation.

As a result, any model attempting to represent the practice of contemporary public diplomacy has to address these audience specifics. In Figure1 the author suggests the adoption of the Yin and Yang Model of the audience in the field.

Figure 1

Yin and Yang Audience Model

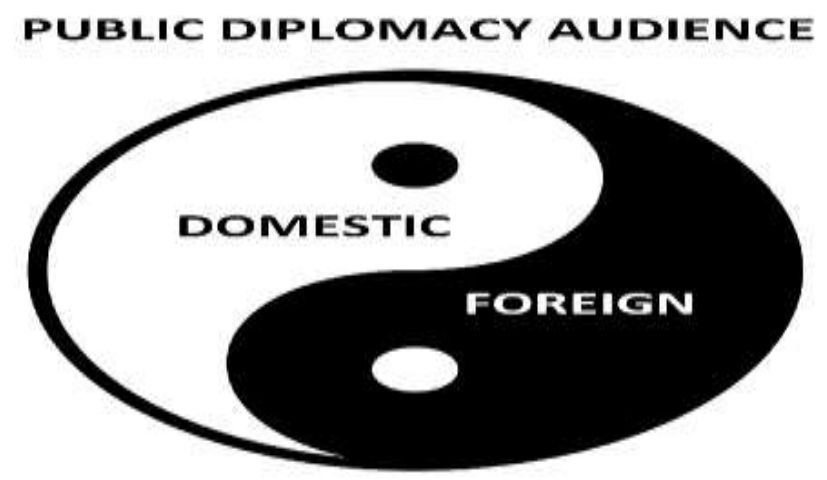


Its visual simplicity is an unorthodox approach towards visualization of the complex audience profile in contemporary international political communication. It can be useful as a basis for further academic analysis or professional inquiry.

The concept of Yin and Yang exists in China since at least 400 B.C. and the illustration itself is called taijitu, reflecting some of the core philosophical principles of the study. Yin and Yang is a Chinese philosophy and metaphysics concept, which describes the way two seemingly contradictory powers, energies and/or principles complement each other as well as their interconnectedness. The author of the article reaches this visualization in search of a suitable representation for the complex nature of the audience in contemporary public diplomacy.

Adhering to the established theoretical frame, the Yin and Yang Model of the audience in public diplomacy illustrates simultaneously internal and external audiences to be targeted by public diplomacy messages. The visualization represents the national diasporas in other countries and the foreign citizens living in a particular state. A reasonable question regarding the need of a model can be raised as we can just assume that public diplomacy has to address everyone. However, the lack of proper segmentation would make it less operational. As a result, the Yin and Yang Model can support better understanding and serve as a platform for further analysis.

\section{Conclusions}

The present article presents a broad theoretical review of the concept of the audience in contemporary public diplomacy. It follows the phenomenon in historical context, starting with its inception. This allows the author to outline the reason behind the initial fragmentation and limitation of practitioners in addressing domestic audiences. Subsequently, newer concepts in the field are investigated, most of which adhere to the idea of including internal state publics as possible receivers of the targeted messages. Last but not least, the legal framework within the US is examined. This is partly because the country is the pioneer of the public diplomacy concept in its contemporary meaning and also because of its reluctance to allow the targeting of the domestic audience by public diplomacy practitioners. However, with the adoption of the SmithMundt Modernization Act of 2012 even the legal framework in the otherwise reluctant country changes to allow its communication force to adapt to the new realities. The presented Yin and Yang Model of public diplomacy can serve as a starting point for future research in the field and might also be useful for practitioners in their strategic communication planning. 


\section{References}

Andrlić, M., Simichen Sopta, S., \& Tarle, I. (2012). Public diplomacy in Croatia: sharing NATO and EU values with the domestic rublic. The Hague Journal of Diplomacy, 7, 483-497. https://doi.org/10.1163/1871191X-12341234

Armstrong, M. C. (2009). Operationalizing public diplomacy. In N. Show \& P. M. Taylor (Eds.), Routledge Handbook of Public Diplomacy (pp. 63-71). Routledge.

Barstow, D. (2008, April 20 ). Behind Tv analysts, Pentagon's hidden hand. New York Times. https://www.nytimes.com/2008/04/20/us/20generals.html

Berridge, G., \& James, A. (2003). A dictionary of diplomacy (2nd ed.). Palgrave Macmillan.

Bjola, C. (2016). Digital diplomacy - the state of the art. Global Affairs, 2(3), 297-299. https://doi.org/10.1080/23340460.2016.1239372

Bravo, V. (2015). The importance of diaspora communities as key publics for national governments around the world. In G. J. Golan, S.U. Yang, \& D. F. Kinsey (Eds.), International Public Relations and Public Diplomacy: Comunication and Engagement (pp. 279-296). Peter Lang Publishing.

Chitty, N. (2009). Australian public diplomacy. In N. Show \& P. M. Taylor (Eds.), Routledge Handbook of Public Diplomacy (pp. 314-322). Routledge.

Cull, N. J. (2009). Public diplomacy before Gullion: the evolution of a phrase. In N. Show \& P. M. Taylor (Eds.), Routledge Handbook of Public Diplomacy (pp. 19-23). Routledge.

Fitzpatrick, K. R. (2007). Advancing the new public diplomacy: a public relations perspective. The Hague Journal of Diplomacy, 2, 187-211.

Fitzpatrick, K. R. (2012). Defining strategic publics in a networked world: public diplomacy's challenge at home and abroad. The Hague Journal of Diplomacy, 7, 421-440. https://doi.org/10.1163/1871191X-12341236

Fominykh, A. (2016). Russia's public diplomacy in Central Asia and the Caucasus: the role of the universities. The Hague Journal of Diplomacy, 1-18. https://doi.org/10.1163/1871191X-12341350

Freeman, R. E. (2010). Strategic management: a stakeholder approach. Cambridge University Press.

Gregory, B. (2015). Mapping boundaries in diplomacys public dimension. The Hague Journal of 
Diplomacy, 1-25. https://doi.org/10.1163/1871191X-12341317

Grunig, J. E., \& Repper, F. C. (1992). Strategic management, publics, and issues. In J. E. Grunig (Ed.), Excellence in Public Relations and Communication Management (pp. 117-157). Lawrence Erlbaum Associates.

Heller, K. S., \& Persson, L. M. (2009). The Distinction between public affairs and public diplomacy. In N. Snow \& P. M. Taylor (Eds.), Routledge Handbook of Public Diplomacy. Routledge.

Huijgh, E. (2012). Public diplomacy in flux: introducing the domestic dimension. The Hague Journal of Diplomacy, 7, 359-367. https://doi.org/10.1163/1871191X-12341240

Kim, J.-N., Ni, L., \& Sha, B.-L. (2008). Breaking down the stakeholder environment: explicating approaches to the segmentation of publics for public relations research. Journalism and Mass Communication Quarterly, 85(4), 751-768.

Kobierecki, M. (2017). The commonwealth games as an example of bringing states closer through sport. Physical Culture and Sport. Studies and Research, 36-43. https://doi.org/10.1515/pcssr

Manor, I. (2017). America's selfie - Three years later. Place Branding and Public Diplomacy. https://doi.org/10.1057/s41254-017-0060-z

Melissen, J. (Ed). (2005). The new public diplomacy: soft power in international relations. Palgrave Macmillan.

Melissen, J. (2011). Beyond the New Public Diplomacy. Clingendael Paper No3. Netherlands Institute of International Relations "Clingendael."

Ogawa, T. (2009). Origin and development of japan's public diplomacy. In N. Show, \& P. M. Taylor (Eds.), Routledge Handbook of Public Diplomacy (pp. 270-282). Routledge.

Pisarska, K. (2015). Peace diplomacy and the domestic dimension of norwegian foreign policy: the insider's accounts. Scandinavian Political Studies, 38(2), 198-215. https://doi.org/10.1111/1467-9477.12042

Pratkanis, A. (2009). Public Diplomacy in International Conflicts: A Social Influence Analysis. In N. Show \& P. M. Taylor (Eds.), Routledge Handbook of Public Diplomacy (pp. 111153). Routledge.

Rana, K. S. (2011). 21st century diplomacy: a practitioner's guide. The Continuum International 
Publishing Group.

Seip, M. (2016). Harnessing Communications and Public Diplomacy. Atlantic Council, 8. http://www.atlanticcouncil.org/publications/issue-briefs/harnessing-communications-andpublic-diplomacy

Signitzer, B., \& Wamser, C. (2006). Public diplomacy: A specific governmental public relations function. Public Relations Theory, 2, 435-464.

Sukma, R. (2011). Soft Power and public diplomacy: the case of Indonesia. In S. J. Lee \& J. Melissen (Eds.), Public diplomacy and soft power in east asia. Palgrave Macmillan.

Vlahos, M. (2009). Public diplomacy as loss of world authority. In N. Show \& P. M. Taylor (Eds.), Routledge Handbook of Public Diplomacy. Routledge.

Yun, S., \& Toth, E. (2009). Future sociological public diplomacy and the role of public relations: Evaluation of public diplomacy. American Behavioral Scientist, 53(4), 493-503.

Zaharna, R. S. (2011). Challenges of strategic stakeholder engagement. In A. Fisher \& S. Lucas (Eds.), Trials of Engagement: The Future of US Public Diplomacy (pp. 201-229). Martinus Nijhoff.

Zöllner, O. (2009). German public diplomacy: the dialogue of cultures. In N. Show \& P. M. Taylor (Eds.), Routledge Handbook of Public Diplomacy (pp. 262-269). Routledge. Kalinov, K. (2021).Publichna diplomazia i terorizam [Public diplomacy and terrorism]. UI "St. Kliment Ohridski. 